\title{
EMBRACING “CONSTITUTIONAL” LEGISLATION: TOWARDS FUNDAMENTAL LAW?
}

\author{
Mark Elliott, Faculty of Law, University of Cambridge*
}

It is traditionally held that, because the United Kingdom Parliament is sovereign, all of the legislation which it passes is, in formal terms, of equal status. As Dicey put it, "neither the Act of Union with Scotland nor the Dentists Act 1878 has more claim than the other to be considered a supreme law". ${ }^{1}$ In fact this conclusion derives from a particular conception of parliamentary sovereignty. The notion that Parliament's legislative supremacy is ongoing or continuing implies that it is the courts' duty to give effect to the most recent expression of Parliament's will. ${ }^{2}$ Consequently, if two pieces of legislation conflict with one another, the courts are obliged to give effect to the more recent expression of Parliament's intention; even if the later Act does not explicitly derogate from the earlier Act, it is capable of repealing it by implication. ${ }^{3}$

This established view of parliamentary sovereignty was, of course, seriously challenged by the accession of the United Kingdom to the European Community and, in particular, by the recognition of the House of Lords in Factortame (No 2) that directly effective Community law may prevail over inconsistent Acts of Parliament. ${ }^{4}$ One of the most surprising features of the Factortame litigation is the paucity of discussion, in their Lordships' speeches, of the constitutional underpinnings and implications of their recognition of the primacy of EC law. For this reason Factortame prompted considerable debate as to whether - and, if so, how - the supremacy of Community law could be explained consistently with the principle of parliamentary sovereignty.

The Administrative Court, in Thoburn v Sunderland City Council, ${ }^{5}$ has now provided a clear answer to this question. The reasoning of the court challenges many aspects of the received wisdom concerning parliamentary sovereignty. In particular, the Court concludes that the ability to repeal legislation by implication is not a necessary concomitant of legislative supremacy; that all legislation is not equal in its constitutional status, and that there exists a category of fundamental constitutional legislation. This paper aims to unpack the significance of Thoburn by considering what light it sheds on our understanding of how the primacy of EC law is accommodated; how it challenges established theoretical accounts of parliamentary

* I am grateful to Trevor Allan and Amanda Perreau-Saussine for their helpful comments on a draft of this article. However, the views expressed, and any errors, are my own responsibility.

1 Dicey, An Introduction to the Study of the Law of the Constitution (1959), p 145.

2 See, eg, Wade in "The Basis of Legal Sovereignty" (1955) 13 CLJ 172.

3 See, eg, Vauxhall Estates Ltd v Liverpool Corporation [1932] 1 KB 733; Ellen Street Estates v Minister of Health [1934] 1 KB 590.

${ }^{4} R \mathrm{v}$ Secretary of State for Transport, ex parte Factortame Ltd. (No 2) [1991] 1 AC 603.

5 [2002] EWHC 195 (Admin) [2002] 3 WLR 247. 
sovereignty, and the implications of its recognition of fundamental law within the UK constitution. First, however, it is necessary to explain the background to the case.

As originally enacted, section 1(1) of the Weights and Measures Act 1985 permitted the use of both metric and imperial units of weight, without preference for one system over the other. However, Council Directive 80/181/EEC requires that metric units should be used in all member states; in consequence, UK law was amended such that it has been unlawful, since 1 January 2000, to sell loose goods in amounts measured in imperial units (albeit that such units can, for the time being, be used alongside metric units in a supplementary capacity). UK law was amended by means of the Weights and Measures Act 1985 (Metrication) (Amendment) Order 1994 (made under a Henry VIII power conferred by section 8(6) of the 1985 Act) and the Units of Measurement Regulations 1994 (made under section 2(2) of the European Communities Act 1972). A number of the appellants - the socalled "metric martyrs" - had been convicted of selling loose goods (fruit, vegetables and fish) from bulk using imperial units, and all of the appellants sought to question the legality of the secondary legislation which had effected the amendments under which they were charged.

\section{“Constitutional” Legislation and Implied Repeal}

The appellants contended that section 2(2) of the 1972 Act did not provide any legal basis for the 1994 Regulations, so that they - and consequently the 1994 Order, which, the Court accepted, ${ }^{6}$ could not rationally stand without the Regulations - were incapable of effecting the amendments under which the appellants had been convicted. They argued that section 1(1) of the 1985 Act, as originally enacted, impliedly repealed section 2(2) of the 1972 Act to the extent that the latter permitted the enactment of any subordinate legislation which would have the effect of derogating from section 1(1) of the 1985 Act. It was said that the policy of Parliament in 1985 was to permit the use of metric and imperial units; and, to the extent that an earlier Parliament had in 1972 created vires to enact measures which would be inconsistent with that policy, the enabling provisions adopted by Parliament in 1972 were impliedly repealed. This argument has potentially dramatic consequences for Henry VIII clauses, since it would render them operative in relation only to earlier legislation. However, Laws $\mathrm{LJ}^{7}$ doubted the soundness of the argument, concluding that there is no inconsistency between a later specific provision and an earlier general provision conferring vires to amend legislation. ${ }^{8}$ In the absence of any inconsistency, no question of implied repeal could arise and the amendment of the 1985 Act therefore rested on a sound legal basis. ${ }^{9}$

However, in case he was wrong on that point, Laws LJ went on to consider a broader question: is the European Communities Act 1972 amenable, in any

6 [2002] 3 WLR 247 at [40].

7 Giving the only reasoned judgment, with which Crane J agreed.

8 [2002] 3 WLR 247 at [50]-[52].

9 And so the appellants' convictions stood. Leave to appeal to the House of Lords was denied by the House of Lords (The Times, 16 July 2002), although an application has now been lodged with the European Court of Human Rights. 
event, to implied repeal by inconsistent provisions in later statutes? The orthodox answer to questions of this nature is well-known: all legislation is vulnerable to express and implied repeal. This follows from the traditional view - adopted in Vauxhall Estates Ltd v Liverpool Corporation ${ }^{10}$ and Ellen Street Estates v Minister of Health ${ }^{11}$ - that Parliament's sovereignty is continuing, such that in cases of conflict priority must be given to the most recent expression of legislative intention. Decisions concerning limitations upon subordinate legislatures ${ }^{12}$ are sometimes advanced as evidence of the courts' willingness to recognise "manner and form" limitations upon the exercise of legislative power; ${ }^{13}$ however, these cases were decided in relation to legislatures exercising powers conferred by the UK Parliament and it is therefore doubtful whether they provide any clear guidance as to the powers of the UK Parliament. ${ }^{14}$

The Vauxhall and Ellen Street cases are therefore usually taken as clearly establishing that the doctrine of implied repeal is a fixed part of domestic constitutional law. However, it is not necessarily appropriate to draw such a broad conclusion from those cases: to do so is (arguably) to dislocate the legal principle which they announced from the context within which they were decided. ${ }^{15}$ The contrary approach was adopted by Laws LJ in Thoburn. In his view the operation of the doctrine of implied repeal is contextsensitive, so that its applicability ultimately depends upon the nature and constitutional role of the legislation in question. The key issue, therefore, is whether the legislation amounts to an "ordinary" or a "constitutional" statute. ${ }^{16}$ The normal principles - including that of implied repeal - operate in relation to the former. However, constitutional statutes - which category comprises legislation that either "conditions the legal relationship between citizen and State in some general, overarching manner" or "enlarges or diminishes the scope of what we would now regard as fundamental constitutional rights" 17 - are to be treated differently. ${ }^{18}$ Thus, Laws LJ explained that, "A constitutional statute can only be repealed, or amended in a way which significantly affects its provisions touching fundamental rights or otherwise the relation between citizen and State, by unambiguous words on the face of the later statute." 19 The meaning of this formula is amplified in the following terms:

"Ordinary statutes may be impliedly repealed. Constitutional statutes may not. For the repeal of a constitutional Act or the

10 [1932] 1 KB 733.

11 [1934] 1 KB 590.

12 See, eg, Bribery Commissioner v Ranasinghe [1965] AC 172; Attorney-General for New South Wales v Trethowan [1932] AC 526.

13 See Jennings, The Law and the Constitution (1959), pp 151-156; Heuston, Essays in Constitutional Law (1964), pp 9-16.

14 See Wade, "The Basis of Legal Sovereignty" (1955) 13 CLJ 172 at 182-183.

15 See Turpin, British Government and the Constitution: Text, Cases and Materials (2002), pp 39-40.

16 [2002] 3 WLR 247 at [62].

17 Ibid.

18 The following are all said to be constitutional statutes: Magna Carta; Bill of Rights 1689; Act of Union; the Reform Acts; European Communities Act 1972; Human Rights Act 1998; Scotland Act 1998; Government of Wales Act 1998.

19 [2002] 3 WLR 247 at [63]. 
abrogation of a fundamental right to be effected by statute, the court would apply this test: is it shown that the legislature's actual - not imputed, constructive or presumed - intention was to effect the repeal or abrogation? I think the test could only be met by express words in the later statute, or by words so specific that the inference of an actual determination to effect the result contended for was irresistible. The ordinary rule of implied repeal does not satisfy this test. Accordingly, it has no application to constitutional statutes." 20

This recognition of a category of "constitutional statutes", and the associated modification of the doctrine of implied repeal, is in many senses novel and raises significant issues concerning the role of legislative supremacy within the UK's constitutional system. The remainder of this paper seeks to explore a number of those issues: the specific question (which supplied the context for the Thoburn decision itself) concerning the relationship between parliamentary sovereignty and EC law; the more general implications of embracing a hierarchy of constitutional laws, and, more broadly still, the relationship between existing theoretical accounts of parliamentary sovereignty and that which is presented in Thoburn.

\section{Parliamentary Sovereignty and the Supremacy of EC Law: Reconciliation through Interpretation?}

Ever since the United Kingdom became a member of the European Community in 1973, constitutionalists have had to confront the apparently irreconcilable principles of the sovereignty of Parliament and the supremacy of EC law. Just as the former is generally regarded as axiomatic as a matter of British constitutional law, so the latter is a fundamental tenet of Community law. European law thus assumes primacy over national law irrespective of whether it post-dates or pre-dates the domestic provision, ${ }^{21}$ and the supremacy principle operates even in relation to municipal constitutional law. ${ }^{22}$ Although British courts acknowledged that circumstances could arise in which EC law would have to take priority over an Act of Parliament, ${ }^{23}$ it was not until almost 20 years after British accession that this actually occurred in Factortame (No 2), in which the House of Lords directed the disapplication of part of the Merchant Shipping Act 1988 on account of its incompatibility with directly effective Community law. ${ }^{24}$

One of the most surprising features of that decision is that, in requiring the disapplication of primary legislation, with all the momentous implications such a step entailed for the sovereignty of Parliament, their Lordships said scarcely a word about how such a development might be accommodated in

20 Ibid, loc cit.

21 Case 6/64, Costa v ENEL [1964] ECR 585.

22 Case 11/70, Internationale Handelsgesellschaft [1970] ECR 1125.

23 See, eg, Macarthys Ltd v Smith [1979] 3 All ER 325.

${ }^{24} R \mathrm{v}$ Secretary of State for Transport, ex parte Factortame Ltd (No2) [1991] 1 AC 603. See also $R$ v Secretary of State for Employment, ex parte Equal Opportunities Commission [1995] 1 AC 1. 
terms of constitutional theory. ${ }^{25}$ Only Lord Bridge went any way towards acknowledging the enormous constitutional significance of the Factortame decision, but even he confined himself to the observation that the supremacy of EC law "was certainly well established in the jurisprudence of the European Court of Justice long before the United Kingdom joined the Community. Thus, whatever limitation of its sovereignty Parliament accepted when it enacted the European Communities Act 1972 was entirely voluntary." 26 But this begs far more questions than it answers, given that the voluntary acceptance of limitations on legislative freedom forms no part of the traditional account of parliamentary sovereignty.

The willingness of the court in Thoburn to address these issues explicitly is therefore as welcome as it is overdue. In particular, the analysis adopted by the Administrative Court facilitates an understanding of the status of EC law within the UK legal system which reconciles it with (a particular version of) parliamentary sovereignty. According to Thoburn, the operation of Community law within the UK is (uncontroversially) to be traced to the European Communities Act 1972; that legislation is the gateway through which EC law passes so as to take effect domestically, and it is therefore that legislation to which we must look in seeking to comprehend how and why EC law operates within the municipal legal system. Thus the domestic position of Community law must depend upon the constitutional status of the 1972 Act, since that is the conduit through which EC provisions acquire force in municipal law. The court concludes in Thoburn that the 1972 Act enjoys constitutional status which, as we have seen, renders it exempt from implied repeal. From this it follows that the legal superiority over domestic law which is afforded to EC law by virtue of the 1972 Act must obtain unless the inconsistent domestic law in question specifically repeals or departs from the 1972 Act. In result, Community law is clothed with the same constitutional protection as the domestic legislation which, in the first place, accounts for its operation in this jurisdiction; it therefore necessarily prevails over all national law in the absence of specific derogation. This approach prompts two particular comments.

First, the Administrative Court's analysis is consistent with the theory of parliamentary sovereignty - or, at least, a specific version of that theory. The model presented in Thoburn does not ultimately contradict the ability of Parliament to derogate from EC law. Such law enjoys priority only because the 1972 Act so provides, and later Parliaments are free to qualify or repeal (partially or wholly) those parts of the 1972 Act which make provision for the effectiveness and status of Community law in the United Kingdom, albeit that they may not do so impliedly. On this view, in the Factortame litigation EC law prevailed over the Merchant Shipping Act 1988 because, first, the 1972 Act provided for Community law to take effect in national law notwithstanding inconsistent provisions in later legislation and, secondly, the legislation enacted in 1988 did not derogate from the position set out in the

25 Although there has, of course, been considerable academic debate. See, inter alios, Craig, "Sovereignty of the United Kingdom Parliament after Factortame" (1991) 11 YEL 221; Laws, "Law and Democracy" [1995] PL 72; Wade, "Sovereignty: Revolution or evolution?" (1996) 112 LQR 568; Allan, "Parliamentary Sovereignty: Law, Politics, and Revolution” (1997) 113 LQR 443.

26 [1991] 1 AC 603 at 658-659. 
1972 Act in an effective manner given the constitutional status of the latter. Parliament in 1988 was therefore substantively sovereign - it could have legislated contrary to EC law - but it omitted to exercise its sovereignty in a manner appropriate to secure that outcome. It follows that recognition of the European Communities Act 1972 (or indeed any other legislation) as constitutional in the Thoburn sense places only formal, and not substantive, fetters on the legislative freedom of Parliament. Ultimately, therefore, the pragmatic form of primacy thus ascribed to EC law is to be traced to the intention of Parliament - albeit an intention which is constructed through the application of particular and novel rules of interpretation - and, in this manner, may be reconciled with the legislature's ongoing substantive sovereignty. ${ }^{27}$

Secondly, the ability of the framework elaborated in Thoburn to accommodate both parliamentary sovereignty and the pragmatic primacy of EC law may appear to be a considerable strength. Indeed such an approach finds its roots deep in British constitutional tradition, whereby long-held orthodoxies are left undisturbed by - yet increasing dislocated from - the realities of governance and political practice. This tendency is clearly illustrated, for example, by the disjunction between the theory and reality of the royal prerogative, ${ }^{28}$ but is perhaps most pronounced in relation to parliamentary sovereignty. ${ }^{29}$ For many, this is a permanent feature of our legal system which, even in the face of radical constitutional and political change, remains constant. The Thoburn judgment classically illustrates this ethos. One of the central messages which it communicates is that Parliament is manifestly sovereign: it is free to do as it pleases, even if this involves derogation from EC law, provided of course that it is sufficiently specific when manifesting its intention. This precisely reflects the typology of constitutionalism which is so familiar in this jurisdiction. Thus all of the benefits which attach to EU membership are purchased by ascribing the pragmatic supremacy to Community law which is an obligatory condition of that membership; and yet this position is secured in a manner which leaves undisturbed the hallowed principle of parliamentary sovereignty, at least at a theoretical level.

The difficulty with this position is that it divorces constitutional theory from political reality. The caveat that Parliament may derogate from EC law provided that it makes specific provision to that effect vouchsafes its theoretical supremacy; but that self-same caveat resonates with a lack of reality. Even if domestic courts recognised the validity of a specific derogation, there would be no question of the European Court of Justice recognising its legitimacy. Short of fundamental Treaty renegotiation on this

27 In fact this approach was foreshadowed by Sir John Laws in "Law and Democracy" [1995] PL 72 at 88-90.

28 The monarch, in law, possesses substantial powers under the royal prerogative; yet, once the legal position is overlaid with constitutional convention, which significantly attenuates the monarch's ability to exercise prerogative powers, the picture changes radically. Thus the traditional legal position is left undisturbed, and expectations of constitutional behaviour are fulfilled through the medium of convention, not law.

29 For discussion see Elliott, "Parliamentary Sovereignty and the New Constitutional Order: Legislative Freedom, Political Reality and Convention" (2002) 22 LS 340. 
point or British withdrawal from the EU, the UK has no option but to accept the primacy of Community law. The putative ability of Parliament, postulated in Thoburn, to derogate specifically from EC law is therefore a largely - if not entirely - theoretical construct: it is, in reality, scarcely more than a device to facilitate adherence to a theory of parliamentary sovereignty which bears little relation to the reality of Westminster's legislative competence within the contemporary constitutional landscape. We will see below, however, that this criticism of Thoburn must be qualified, because the judgment also looks beyond this solution by anticipating the possibility that, in the longer term, the constitutional status of EC law may be reflected at a theoretical, not just a pragmatic, level.

\section{Constitutional Legislation and Constitutional Rights: Towards a Hierarchy of Norms}

The approach commended by Laws LJ in Thoburn is novel to the extent that it marks out certain legislation as being constitutional in nature and attaches specific legal consequences to that categorisation. To some extent, however, it echoes Laws J's earlier judgment in $R \mathrm{v}$ Lord Chancellor, ex parte Witham which was given in a distinct, yet closely analogous, context. The key question in that case was whether legislation could, through the use of general words, attenuate or displace citizens' access to the courts. Laws J opined that access to the courts was recognised by the common law as a "constitutional right"; but, recognising that in the face of parliamentary sovereignty no right could be absolute, Laws $\mathrm{J}$ concluded that such rights were to be protected by means of interpretation, such that they could be displaced or qualified only by express legislative provision to that effect. ${ }^{30}$ The relationship between constitutional rights and constitutional legislation is of interest for two reasons.

First, the concepts sit comfortably together, since each rests on the same premises: that the constitutional value of particular norms and governmental arrangements ought to be reflected in law, thus eschewing the unhelpful dogma that our constitution knows no hierarchy of values, but that - at least at the current stage of the British constitution's evolution - the fundamentality of such norms may be acknowledged only by means of interpretation. In this manner, the interpretative machinery invoked by the doctrines of constitutional rights and constitutional legislation facilitates legal recognition of a hierarchy of constitutional norms without, for the time being, disturbing the orthodox principle of parliamentary sovereignty. It is, moreover, entirely appropriate that the same approach obtains in relation to both common law constitutional rights and constitutional legislation: in each case the judiciary is (of necessity, in the absence of any constitutional text) determining that particular constitutional weight is to be ascribed to the value or rule in question, and that legal consequences ought to attach to the constitutional importance of the provision. It would be unfortunately formalistic to draw a distinction between common law and legislative provisions in this regard; and, by extending to constitutional legislation the

30 [1998] QB 575. Although, at one point in his judgment, Laws J speaks of "specific provision" (p 581), he later makes it clear that this means express provision (pp 585-586). 
interpretative approach first applied to common law rights, Thoburn represents an important and positive development.

Secondly, however, the interpretative approach adopted in relation to constitutional rights and statutes will inevitably raise difficulties of construction. ${ }^{31}$ What, precisely, constitutes a provision sufficiently "specific" to override constitutional legislation? Laws $\mathbf{J}$ concluded in Witham that constitutional rights could be displaced only by express provision. However, in $R$ v Secretary of State for the Home Department, ex parte Pierson, Lord Browne-Wilkinson doubted the correctness of this approach. Although he agreed that "basic rights are not to be overridden by the general words of a statute since the presumption is against the impairment of such basic rights", he apparently felt that such rights might be displaced by broader means than purely express provision. ${ }^{32}$ In the analogous context of constitutional legislation, Laws LJ appears to have taken this point into account in his judgment in Thoburn. Thus he refers to "specific" rather than "express" derogation from constitutional legislation, and accepts that this includes both "express words in the later statute" and "words so specific that the inference of an actual determination to effect the result contended for was irresistible". ${ }^{33}$

This is surely the correct approach, since it avoids the formalism - and, ultimately, the artificiality - inherent in seeking to draw a bright-line distinction between express and non-express repeal. ${ }^{34}$ Instead, it captures the underlying and crucial point that, in a mature legal system, fundamental values must be accorded a measure of constitutional security which protects them against casual or incidental erosion, and which requires the legislature to consider their displacement - and to express its conclusions on this matter - in the clearest possible terms. Thus the approach commended in Thoburn will inevitably raise problems of interpretation; but they are problems which necessarily and rightly arise once we abandon the dogma that our legal system lacks any hierarchy of constitutional values.

\section{The Wider Picture: Legislative Power and the Common Law Constitution}

Within the constitutional framework set out by the Administrative Court in Thoburn the process of statutory interpretation occupies centre-stage. The strength of this approach, as we have seen, is that it acknowledges a hierarchy of constitutional values while still adhering to the established orthodoxy of parliamentary sovereignty. However, as noted above, the

31 As Marshall (2002) 118 LQR 493 at 495-496 observes.

32 [1998] AC 539 at 575.

33 [2002] 3 WLR 247 at [63].

34 But it is arguable that Thoburn still suffers from formalism in a different context. By drawing a distinction between constitutional and ordinary legislation, the decision implies a clear choice between two styles of interpretation. It seems more likely that, as the case law in this area develops, a more subtle approach will emerge according to which the strength of the rule of interpretation applied to a particular provision - and hence the degree of specificity required to secure its repeal - will vary according to the degree of constitutional importance attached to it. 
reverse side of this coin is that legal theory tends to become dislocated from political reality. For instance, the idea that Parliament remains notionally competent to derogate from EC law misrepresents the reality of the contemporary political order within which the United Kingdom, as a member of the EU, is bound to adhere to Community law. This style of reasoning, according to which the appearance of orthodoxy is preserved at the expense of a legal theory which accurately describes political reality, typifies the pragmatic British approach to constitutionalism.

To an extent, Thoburn perpetuates that tradition; but the case also tentatively points away from this style of reasoning. Although the court concludes that Parliament is, for now, sovereign, that position is not represented as an immovable one because, crucially, the concept of legislative power is conceptualised by the court in dynamic, not static, terms. Consequently, while the immediate relevance of Thoburn is its articulation of a novel category of constitutional legislation which is protected through statutory construction, the more abstract - but, in the longer term, potentially much more significant - impact of the case lies on a broader canvas, since it anticipates a constitutional scheme within which Parliament's role is subtly but significantly - different from that which it presently occupies. Laws LJ expresses the point in the following terms:

"Parliament cannot bind its successors by stipulating against repeal, wholly or partly, of the [European Communities Act 1972]. It cannot stipulate as to the manner and form of any subsequent legislation. It cannot stipulate against implied repeal any more than it can stipulate against express repeal ... The British Parliament has not the authority to authorise any [limitations upon its own powers]. Being sovereign, it cannot abandon its sovereignty ... This is, of course, the traditional doctrine of sovereignty. If it is to be modified, it certainly cannot be done by the incorporation of external texts [such as the European Community Treaty]. The conditions of Parliament's legislative supremacy in the United Kingdom necessarily remain in the UK's hands. But the traditional doctrine has in my judgment been modified. It has been done by the common law, wholly consistently with constitutional principle." 35

Two points are pivotal within this view of the constitutional order, and of Parliament's place within it. The first concerns the source of legislative authority. In Laws LJ's view Parliament's power to enact law is derived from, and thus conferred by, the common law. This is necessarily implicit in his assertion that the conditions upon which legislative authority is held can be - and indeed have been - modified by the common law. Secondly, if it is accepted that legislative power derives from the common law, then it follows a priori that the scope of that legislative power is not fixed. Parliamentary sovereignty, on this view, is not an immovable feature of the constitutional system: rather, it expresses the conclusion which the common law has

35 [2002] 3 WLR 247 at [59], per Laws LJ. 
reached, for the time being, as to the width of Parliament's legislative competence. Crucially, as the common law evolves in light of changing circumstances - both internal and external to the UK's political order - so the common law conditions upon which Parliament's legislative authority is held may change in turn. Indeed this possibility is explicitly countenanced by Laws LJ in his judgment, and he concludes that such change has, in fact, already occurred:

"The common law has in recent years allowed, or rather created, exceptions to the doctrine of implied repeal: a doctrine which was always the common law's own creature. There are now classes or types of legislative provision which cannot be repealed by mere implication. These instances are given, and can only be given, by our own courts, to which the scope and nature of Parliamentary sovereignty are ultimately confided. The courts may say - have said ${ }^{36}$ - that there are certain circumstances in which the legislature may only enact what it desires to enact if it does so by express, or at any rate specific, provision." 37

Thus, precisely because parliamentary sovereignty's nature and scope are a function of the common law - and are hence "ultimately confided" to the courts - those phenomena are prone to change as the common law, and the constitutional and political environment within which it is located and to which it gives legal effect, evolve. To date, as Laws LJ recognises, the extent to which the common law has changed in this regard is relatively modest. Hence the fundamentality of certain rights and of certain legislative provisions is secured by the application of new principles of interpretation which reflect the common law's conclusion that it is no longer constitutionally appropriate to ascribe to Parliament a legislative competence to abrogate such rights and arrangements implicitly.

But just as the common law has evolved so to arrive at this position at the present time, so further evolution is possible within this model. Ultimately, therefore, if the view of parliamentary sovereignty presented in Thoburn is accepted, then it is necessarily possible that the common law may, at some future point, arrive at the conclusion that there are certain constitutional values or constitutional arrangements whose normative value is so great as to place them beyond any interference - specific or otherwise - by the legislature. Consequently, while such key features of the British constitution such as human rights, membership of the EU and the existence of devolved institutions of government are all currently thought to be ultimately vulnerable in the face of an exercise of sovereign legislative power, Thoburn presents a view of the constitutional order in which the present subordinate status of such norms and structures may, in the future, change. ${ }^{38}$

36 In relation to common law constitutional rights and EC law.

37 [2002] 3 WLR 247 at [60].

38 For discussion of the impact on parliamentary sovereignty of devolution and the incorporation of the European Convention on Human Rights, see Elliott, "Parliamentary Sovereignty and the New Constitutional Order: Legislative Freedom, Political Reality and Convention" (2002) 22 LS 340. 
This possibility inevitably arises if it is acknowledged that parliamentary sovereignty is not abstract or given, and that legislative authority is a common law construct whose reach is to be evaluated and determined within the context of contemporary constitutionalism and by reference to the extent and nature of the fundamentality which that constitutionalism ascribes to its central norms, structures and arrangements. Indeed, this dynamic conception of legislative authority was made even more explicit by Laws LJ in his judgment in International Transport Roth $\mathrm{GmbH} \mathrm{v}$ Secretary of State for the Home Department, in which he opined that, "In its present state of evolution, the British system may be said to stand at an intermediate stage between parliamentary supremacy and constitutional supremacy. . ."39 In result, although the common law presently acknowledges only formal limitations upon parliamentary competence, it is logically implicit within the model of constitutionalism set out in Thoburn ${ }^{40}$ that the common law conditions upon which Parliament's law-making powers are held may, in the future, come to constrain those powers substantively. ${ }^{41}$

\section{Re-evaluating Sovereignty Theory}

Whether the articulation and enforcement of such constraints represents a legitimate judicial task, in the absence of a written constitution conferring such power upon the judiciary, is a well-rehearsed debate. For some, such judicial activism would represent an illegitimate arrogation of power wholly at odds with the role of the courts under the received perception of the separation of powers as it applies in the UK. ${ }^{42}$ But for others, a process whereby the judiciary, through its interpretation of the common law constitution, articulates and gives legal force to the constitution's most fundamental values is the hallmark of true democracy, in which it is acknowledged that there exist norms whose legitimacy precedes even the claims of the represented majority. ${ }^{43}$ It is beyond the scope of this paper to participate directly in that debate; rather, it has attempted to demonstrate that the decision in Thoburn, by presenting a judicial vision of the constitutional order which raises the possibility of legal limitations upon Parliament's competence, breaks new ground and adds a new relevance to the debate about the legitimate extent, in this context, of judicial activism. It is appropriate, therefore, to examine by way of conclusion exactly how Thoburn challenges established accounts of parliamentary sovereignty.

39 [2002] EWCA Civ 158 [2002] 3 WLR 344 at [71] (emphasis added).

40 And also in International Transport Roth GmbH.

41 Unsurprisingly, these conclusions about the potential implications of Thoburn are entirely of a piece with the views which Sir John Laws has expressed extracurially in this area. See principally "Judicial Remedies and the Constitution" (1994) 57 MLR 213, "Law and Democracy" [1995] PL 72 and "The Constitution: Morals and Rights" [1996] PL 622.

42 See, for example, Griffith, "The Brave New World of Sir John Laws" (2000) 63 $M L R 159$

43 Such views receive prominent support from Laws, "Law and Democracy" [1995] PL 72; Allan, Law, Liberty, and Justice: The Legal Foundations of British Constitutionalism (1993), ch 11 and Constitutional Justice: A Liberal Theory of the Rule of Law (2001), ch 7; Cooke, "Fundamentals" [1988] New Zealand Law Journal 158. 
The framework articulated in Thoburn shares similarities with both the "continuing" theory and the "new view", but also differs from each of them in important respects. As is well known, the new view - advanced by Jennings $^{44}$ and supported by Heuston ${ }^{45}$ - holds that, while Parliament may not impose substantive limitations upon its successors, it may subject them to constraints of manner and form. The outcome of the reasoning applied in Thoburn appears to support this theory since the European Communities Act 1972 is regarded as beyond implied repeal; this seems to suggest that, in enacting that legislation, Parliament succeeded in imposing a formal limitation upon its successors, requiring them to use specific language should they wish to depart from the 1972 Act. ${ }^{46}$ However, although the outcome of Thoburn appears compatible with the new view, the reasoning applied by the court is not. Although Parliament is now subject to a formal restriction visà-vis derogation from the 1972 Act, the conclusion reached in Thoburn is that the source of this restriction does not lie in any legislative intention manifested by Parliament in 1972. Indeed, the possibility of Parliament's imposing such restrictions upon its successors was explicitly rejected by the court:

"Parliament cannot bind its successors by stipulating against repeal, wholly or partly, of the [European Communities Act 1972]. It cannot stipulate as to the manner and form of any subsequent legislation. It cannot stipulate against implied repeal any more than it can stipulate against express repeal." ${ }^{47}$

The true explanation, according to Thoburn, for the emergence of the formal requirement relating to the 1972 Act is that the common law recognises it as a constitutional statute and attaches a particular legal condition - immunity from implied repeal - to such legislation. The formal limitation upon legislative competence which has emerged in relation to the 1972 Act therefore owes its existence to the development of the common law rather than to any manifestation of legislative intention. Consequently, while the outcome of Thoburn is that Parliament is now subject to formal restrictions vis-à-vis constitutional legislation, this does not invoke or support the new view. Indeed it directly contradicts that view by denying Parliament the ability to entrench legislation itself and by concluding that, instead, questions of entrenchment are ultimately to be determined through judicial application and development of the common law conditions upon which Parliament's legislative authority is held.

This forms a considerable advance on the new view as postulated by Heuston and Jennings. Their approach calls for highly artificial distinctions to be drawn between, on the one hand, manner and form limits and, on the other hand, substantive limits. ${ }^{48}$ And, even if the distinction between the two

44 Jennings, The Law and the Constitution (1959), pp 151-156.

45 Heuston, Essays in Constitutional Law (1964), ch 1.

46 Or from EC law whose effectiveness is, in the first place, provided for by the 1972 Act.

47 [2002] 3 WLR 247 at [59].

48 Wade gives the example of an Act rendered practically beyond repeal by a requirement that the support of ninety per cent of the electorate must first be secured. See "The Basis of Legal Sovereignty" (1955) 13 CLJ 172 at 181. 
forms of entrenchment can be maintained, it still ascribes to the legislature an unfettered competence to entrench its enactments by means of potentially very powerful manner and form limits. In contrast the model presented in Thoburn provides for independent judicial scrutiny before any legislation is recognised as being entrenched to any extent. In this manner any legislative attempt to entrench legislation must be examined by the judiciary against a wider constitutional backdrop, in order to determine whether the entrenchment of the legislation in question would be constitutionally appropriate. Thoburn therefore reflects an approach to questions of entrenchment which is far more contextual than that which is postulated by the new view.

Criticising the new view (among others), Allan observes that, "Almost all modern discussions of sovereignty share the error of seeking to provide a single determinate solution which can be applied, in advance, to every question concerning the limits of the doctrine which may arise in the future." ${ }^{49}$ He goes on to suggest that the correct approach to questions of entrenchment demands analysis of the context within which they arise. Thus, "The boundaries of sovereignty must be determined in the light of the prevailing moral and political climate when difficult questions of constitutional authority arise." ${ }^{50}$ By denying the legislature any automatic right to entrench legislation, Thoburn commends an approach similar to that which Allan advocates since, if Parliament ultimately holds its legislative authority subject to common law conditions, then it is for the judiciary, by interpreting the common law constitution and determining the role played by the enactment in question within that constitution, to decide whether and how it may be repealed. This, it seems, marks a more mature and measured approach to matters of entrenchment than the rather formalistic new view. It necessarily engages the judiciary in difficult issues; but, given that such issues will inevitably arise, it is surely better that they are resolved in a manner suitable to the context rather than by the mechanical application of a rule which takes no account of the specific issues at stake.

The model set out in Thoburn also differs from the continuing theory which was classically set out by Wade. ${ }^{51}$ That theory essentially treats parliamentary sovereignty as a political fact; the doctrine is taken to describe the relationship between Parliament and the courts, and its ongoing applicability is therefore dependent upon the courts' continued acquiescence in that relationship. Importantly, however, the courts have no choice but to acquiesce if they are to act with constitutional propriety: the relationship described by the doctrine of parliamentary sovereignty is, we are told, immovable so long as the present constitutional order subsists. It is for precisely this reason that Wade is forced to explain any changes in the conditions upon which legislative authority is held in terms of an extraconstitutional "revolution".52 By shifting the basis of the relationship between the courts and the legislature, the judiciary acts unconstitutionally by failing to adhere to the relationship dictated by the sovereignty principle.

49 Allan, "The Limits of Parliamentary Sovereignty" [1985] PL 614 at 624.

50 Ibid, p 627.

51 "The Basis of Legal Sovereignty" (1955) 13 CLJ 172.

52 Ibid, p 189. 
Following such judicial action the new constitutional landscape must be understood as the product of discontinuity since, if the constitutionally impossible actually happens, it must occur extra-constitutionally: the old, immutable grundnorm must logically have been replaced by a new one. Wade pursues this line of analysis in addressing the decision in Factortame (No 2), concluding that the House of Lords' refusal to recognise the effectiveness of an Act of Parliament evidences the removal of judicial support from the relationship between courts and Parliament which the doctrine of legislative supremacy embodied. ${ }^{53}$

In one important respect, the version of parliamentary sovereignty advanced in Thoburn is very similar to Wade's. On both views, the courts occupy a pivotal role. Thus Wade holds that Parliament's legislative powers lie "in the keeping of the courts" ${ }^{4}$ while, to similar effect, the Administrative Court's analysis is premised upon the notion that legislative authority is subject to those conditions which are prescribed by the courts through the common law. At this point, however, the similarity between the two views ends. The characterisation (which is dictated by Wade's theory) of the House of Lords' behaviour in Factortame as revolutionary - and therefore in some way extra-constitutional - is highly artificial. More fundamentally, Wade's view of parliamentary sovereignty as a constitutional given - a "political fact" $" 55$ - raises a whole series of difficulties. It fails to supply a satisfactory normative justification for the existence and width of Parliament's law-making powers, and it renders legislative authority a phenomenon which is separate from law. This, in turn, insulates the doctrine of parliamentary sovereignty from the usual processes whereby legal principles are evaluated, interpreted and, where necessary, reinvented in order that they are rendered appropriate in light of a whole matrix of other considerations, not least the prevailing fundamental values embraced by the political and constitutional order.

The model advanced in Thoburn differs subtly but importantly from Wade's. Although the courts still play a central role, the conceptual starting-point according to which legislative authority is neither above nor separate from, but is rather subject to, law - fundamentally changes the way in which we understand the courts' function. No longer does parliamentary sovereignty describe a factual relationship which may be changed only by unconstitutional behaviour on the courts' part; nor is legislative supremacy an immovable constitutional fact which needs no justification and is invulnerable to constitutional change. Once legislative authority is acknowledged to be a legal phenomenon which is subject to the common law, the judicial role changes substantially. It is, under the Thoburn view, the courts' task to interpret the nature and extent of legislative authority by reference to, and in a manner appropriate to, the content and values of the contemporary constitution. Alterations in the nature and scope of legislative authority are thus no longer to be regarded as aberrations evidencing a discontinuity wrought by judicial disobedience to the established order; such

53 Wade, “Sovereignty - Revolution or Evolution?" (1996) 112 LQR 568.

54 Wade, "The Basis of Legal Sovereignty" (1955) 13 CLJ 172 at 189.

55 Ibid, loc cit. 
alterations, instead, are a legitimate consequence of the courts' discharging their constitutional role.

In purely pragmatic terms, the roles occupied by the judiciary under Wade's view and under Thoburn do not differ radically. In each case the judiciary may ultimately determine the limits of legislative authority. However, according to the continuing theory the judiciary holds this power only on a pragmatic level, such that its exercise involves extra-constitutionality or discontinuity: in other words, it involves the judges arrogating to themselves a role which is not constitutionally theirs. In contrast Thoburn envisages that it is the courts' constitutional function to interpret the contemporary constitution and thereby determine the proper scope of legislative authority. This difference is key. It affects how we think about the constitution and law-making power at the most fundamental level, since it determines whether legislative authority is ultimately subject to the unwritten constitution or to the merely pragmatic response of the judiciary. In result, the approach commended in Thoburn places the judiciary on much more secure ground in discharging its function of determining the limits of parliamentary sovereignty - a function whose existence Wade is forced to concede, albeit at a pragmatic level only. Thoburn renders this process legal in nature, and thus envisages a limited judicial role which is to be discharged by reference to the constitution. In this way the judiciary does not - in contrast to the position logically inherent in the continuing theory - exercise an ultimately unfettered discretion in determining what is to be recognised as law; rather, its duty is to apply those criteria which are implicit in the constitutional order. ${ }^{56}$

This point is well made by Allan who, in criticising Wade's analysis of Factortame as evidence of revolutionary change in the constitutional order, comments that:

". . . it is scarcely possible to argue [as Wade does] both that changes in the rule of recognition are made or acknowledged for 'good legal reasons' and that such a rule constitutes only a 'political fact', subject to alteration for reasons of 'political necessity'. Legal reasons are usually understood to ground a legitimate judicial decision by invoking settled doctrine or principle: they serve to justify it by explaining the sense in which it was required by the standards of the existing legal order. A revolution occurs, or is cemented, only when a new source of authority is acknowledged, or fundamental rule adopted, which is not justified by the existing order, from which the courts have for whatever reason withdrawn their allegiance." ${ }^{57}$

56 An important difficulty, of course, lies in determining precisely what the unwritten constitution requires in this regard. For discussion, see Elliott, "Parliamentary Sovereignty and the New Constitutional Order: Legislative Freedom, Political Reality and Convention" (2002) 22 LS 340.

57 Allan, "Parliamentary Sovereignty: Law, Politics, and Revolution" (1997) 113 $L Q R 443$ at 444 (original emphasis), quoting from Wade, "Sovereignty Revolution or Evolution?" (1996) 112 LQR 568. 
Allan's point is that one cannot have it both ways: either sovereignty is purely a question of political fact, untouched and ungoverned by legal reasoning, or it is a question of constitutional law. And, in turn, judicial decision-making in this area represents either a wholly pragmatic and ultimately unfettered response to political change, or it is a form of constitutional adjudication, reliant upon legal reasoning and constrained by the terms of the constitution with whose interpretation the judiciary is centrally concerned. Factortame demonstrates that judicial decision-making in this context is inevitable. Given that reality, surely it is vastly preferable that such decision-making is treated in the latter sense, in order that the judiciary's role is constrained by law and by the constitution, and in order that the legitimacy of such adjudication may be properly measured and evaluated.

\section{CONCLUSION}

The decision of the Administrative Court in Thoburn v Sunderland City Council is of constitutional significance in three principal respects. In the first place it provides an explanation of EC law's status within the UK legal system which is far more coherent than any earlier judicial offering in this context. It elegantly ascribes a pragmatic form of primacy to Community law without, for the time being, displacing the doctrine of parliamentary sovereignty. Although the mechanism used to achieve this objective - based on Parliament's notional ability to derogate specifically from EC law - has been criticised in this paper because it fails to intersect with the political reality of the contemporary constitutional landscape, we have seen that, because of the wider analysis of parliamentary sovereignty presented in Thoburn, this shortcoming is potentially only temporary, and a necessary staging-post in the evolutive development of the common law constitution as it begins to confront the possibility of substantive restrictions on Parliament's competence to enact and change UK law.

Secondly, Thoburn marks, in a sense, the UK constitution's coming of age. It acknowledges the existence of a hierarchy of values and provisions within the British constitution by announcing a new category of constitutional legislation and relating this to the already established notion of common law constitutional rights. In this manner Thoburn dispenses with the Diceyan dogma that, within our legal system, all laws are equal. The interlocking regime of constitutional legislation and constitutional rights for which the Administrative Court's judgment lays the foundation is to be welcomed, and marks an important stage in the development of constitutional adjudication in the absence of a written constitution; and the strong interpretative protection now extended to constitutional statutes and rights in turn confers a substantial measure of security upon constitutional governance in the face, for the time being, of a sovereign legislature.

The third aspect of the judgment in Thoburn is of least immediate relevance, but is potentially of most far-reaching significance. In Thoburn the Administrative Court presents a vision of the British constitutional order which is subtly but importantly different from received constitutional orthodoxy and, thus, from the views encapsulated in many leading theories of parliamentary sovereignty. The approach advocated in Thoburn renders legislative authority a legal phenomenon which is subject to law and thus to adjudication by the courts. Acceptance of such a framework does not, 
however, give the judiciary a free hand in determining the limits of parliamentary sovereignty, and it does not permit the imposition, upon the elected branch of the constitution, of the judiciary's own policy preferences and concerns. The impact of EC law upon the British constitution vividly illustrates that adjudication upon matters of parliamentary sovereignty - and, ultimately, determining the limits of the legislature's authority - is a task which inevitably arises. Moreover, recent changes to the architecture of the British constitution - notably the incorporation, through the enactment of the Human Rights Act 1998, of the European Convention on Human Rights, and the introduction of systems of devolved government in Northern Ireland, Scotland and Wales ${ }^{58}$ - illuminate with particular clarity the tension lying at the heart of a constitutional order which ascribes unlimited power to its legislature $^{59}$ while simultaneously seeking to acknowledge the normative importance of such matters as fundamental rights and regional autonomy. Notwithstanding that the human rights and devolution legislation - like the European Communities Act 1972, on one interpretation at least - are formally compatible with the ongoing supremacy of the Westminster Parliament, that concept sits at best uneasily alongside the notion of fundamental constitutional rights and the idea that, as Lord Bingham recently put it, the Northern Ireland Act 1998 - and, by extension, the other devolution legislation - "is in effect a constitution". ${ }^{60}$

In the face of such difficulties, the usual British response has tended to follow one of two approaches. Most commonly, it has been accepted implicitly that there exists a dislocation between constitutional theory, which allocates absolute law-making power to Parliament, and political reality, which recognises the fundamentality of certain values and structures. In this way, the appearance of orthodoxy is preserved at the expense of its relation with reality. The alternative response is to abandon - in more explicit terms - constitutional law and constitutional theory, and to rely upon pragmatic accounts founded on the ultimate dependence of legislative authority upon the acquiescence of the judiciary: it is, for instance, in this manner that Wade accounts for the emergence of limitations, based on EC law, on Parliament's legislative competence. ${ }^{61}$ Both of these approaches are flawed. The former invokes a constitutional theory which fails to coincide with the reality of the contemporary political environment, while the latter relies upon a normatively barren account of legislative authority which implies that its foundations lie in nothing more convincing than raw judicial recognition of legislative power.

The approach put forward by the Administrative Court in Thoburn represents a considerable advance. It allows constitutional theory fully to reflect constitutional reality and, in particular, the true position of the legislature. Such an approach undeniably raises a great number of difficulties as the judiciary embarks upon the task of interpreting the unwritten constitutional order and moves towards a position in which the limits upon legislative authority are more clearly and boldly articulated than has hitherto been the

58 See respectively Northern Ireland Act 1998; Government of Wales Act 1998; Scotland Act 1998.

59 Or, more accurately in this era of devolved government, its central legislature.

60 Robinson v Secretary of State for Northern Ireland [2002] UKHL 32 at [11].

61 See Wade, “Sovereignty: Revolution or evolution?" (1996) 112 LQR 568. 
case. In particular, considerable attention will have to be paid to determining the constitutional criteria by reference to which the judiciary is to identify the limits of parliamentary sovereignty. But this, in itself, is a strength as well as a problem. In contrast to the traditional approach - under which such judicial decision-making is inevitable yet necessarily obscured by the veil of extra-constitutionality which is taken to characterise it - a model which renders questions of sovereignty subject to constitutional adjudication makes that process of adjudication open to scrutiny and evaluation. Ultimately, difficulties of this nature are the hallmark of mature constitutionalism; and the fact that the judiciary, in Thoburn, has tentatively pointed towards a constitutional environment in which such problems may eventually arise is a development to be welcomed, not feared. 